\title{
Analiza ryzyka w certyfikacji poszczególnych etapów cyklu życia biopaliw
}

\begin{abstract}
Niniejsze opracowanie prezentuje problematykę oceny ryzyka w certyfikacji biopaliw stosowanej w ramach wybranych systemów certyfikacji. W artykule przedstawione zostało ujęcie problemu stawianego jednostkom certyfikującym przez właścicieli poszczególnych systemów oraz praktyczne sposoby jego rozwiązywania w SGS Polska. Porównaniu poddano wymagania dotyczące analizy ryzyka w ramach trzech uznanych przez Unię Europejską standardów: KZR INiG, REDcert i ISCC. Każdy z nich określa sposób postępowania w ramach szacowania ryzyka, którego celem jest ocena potencjalnych negatywnych skutków wynikających z braku realizacji wymogów dyrektywy RED przez podmiot poddający się certyfikacji oraz prawdopodobieństwa ich wystąpienia, co szczegółowo opisano w artykule. Niezależnie od systemu oszacowanie ryzyka dla podmiotu podlegającego audytowi na zgodność z wymaganiami danego standardu ma istotne znaczenie w dalszym procesie certyfikacyjnym. Przypisany przed przystąpieniem do oceny podmiotu poziom ryzyka daje możliwość określenia wielkości próbki badanej podczas audytu, celem dokładnego przeanalizowania procesu realizowanego w przedsiębiorstwie zgodnie z wymogami danego standardu. Realizacja procesu u podmiotu podlegającego ocenie nie ma jednoznacznego wpływu na szacowanie poziomu ryzyka, dlatego tak istotne jest, by analizę ryzyka przeprowadzać regularnie na podstawie zgłoszonych informacji.
\end{abstract}

Słowa kluczowe: analiza ryzyka, KZR INiG, REDcert, ISCC, dyrektywa RED, certyfikacja biopaliw, wymogi zrównoważonego rozwoju.

\section{Risk analysis at various stages of the certification of the biofuel lifecycle}

\begin{abstract}
The paper presents the issue of risk assessment in the certification of biofuels used in different certification schemes. The article presents a theoretical background of the issue with which certification bodies are faced with through scheme owners and presents practical implementation of solutions at SGS Polska. The risk analysis requirements of three schemes approved by the European Commission: KZR INiG, REDcert and ISCC have been compared. Each of these three schemes determines a risk assessment procedure, with the final goal of assessing potential negative effects from not implementing the so called RED Directive by the entity undergoing a certification process and the probability of their occurrence, which is detailed within the article. Regardless of the certification scheme in question, the risk analysis of the entity to be audited for compliance with a given standard is essential in the further certification process. An assigned risk level defined prior to the actual assesment gives an opportunity to determine the size of the audit sample, in order to accurately analyze the processes of a company according to the requirements of the implemented standard. Correct process implementation in the entity being subject to the assessment has no clear impact on the estimation of the risk level, therefore it is crucial that the risk analysis is carried out regularly on the basis of the collected information.
\end{abstract}

Key words: risk analysis, KZR INiG system, REDcert, ISCC, RED Directive, biofuels certification, sustainability requirements.

\section{Wprowadzenie}

Pojęcie ryzyko pochodzi od starowłoskiego risicare, co oznacza odważyć się. Na tej podstawie można wnosić, że ryzyko należałoby łączyć z wyborem, decyzją, a nie z prze- znaczeniem [2]. W literaturze przedmiotu można doszukać się wielu definicji tego terminu, jednak jednoznacznie daje się stwierdzić, że ze słowem ryzyko ściśle wiąże się pojęcie 
straty. Uzasadnione jest zatem przeprowadzanie w danym procesie analizy ryzyka, mającej na celu ocenę potencjalnych negatywnych skutków badanego przedsięwzięcia i odpowiadających im prawdopodobieństw (częstości występowania). Przy dokonywaniu takiej analizy należy mieć na uwadze, że ryzyko można oszacować i redukować, ale nie da się go całkowicie wyeliminować. Stąd też weryfikację ryzyka należy przeprowadzać co pewien czas ze względu na możliwość pojawienia się nowych czynników mających wpływ na jego wartość.

Zagadnienia dotyczące ryzyka można odnosić do funkcjonowania całej organizacji bądź zawęzić do wybranego obszaru. Tę problematykę szczegółowo opisano w publikacjach Międzynarodowej Organizacji Normalizacyjnej ISO w wytycznej ISO Guide 73 [8] i normie ISO 31000:2012 [7]. W związku z intensywnym rozwojem wszelkich dziedzin przemysłu w ostatnich latach procesy dotyczące ryzyka i redukowania jego następstw również przebiegają dynamicznie. Nieustannie postępujący rozwój technologiczny i cywilizacyjny niesie za sobą ciągle nowe elementy ryzyka w obszarze takich zjawisk jak: innowacje w procesach technologicznych, oddziaływanie na środowisko, przetwarzanie danych, zmieniające się regulacje prawne i rozwiązania polityczne. Zawsze występuje ryzyko niespełnienia wymagań, co w efekcie prowadzi do nieosiągnięcia zamierzonych celów. Naturalnym procesem jest przekładanie się występującego ryzyka na funkcjonowanie całej organizacji, realizowane procesy produkcji wyrobu czy jakość świadczonych usług. Uzasadnione jest zatem określenie ryzyka i sposobu redukowania jego skutków metodami, które będą najwłaściwsze do rozwiązywania występujących problemów.

W związku z istotnością zagadnienia ryzyka stosowanie znormalizowanej, uznanej w świecie terminologii ma kluczowe znaczenie dla zrozumienia istoty problemu. Istnieje wiele źródeł podających informacje lub wymagania odnoszące się do ryzyka, niejednokrotnie jednak sprzeczne. $Z$ tego powodu także systemy wspierające procesy certyfikacji produkcji biopaliw i biopłynów zostały zbudowane w oparciu o termi- nologię podaną w normach wydanych przez Międzynarodową Organizację Normalizacyjną ISO.

Zgodnie z normą ISO 31000:2012 ryzykiem określono wpływ niepewności na cele, przy czym wpływ ten powoduje pozytywne i/lub negatywne odchylenie od oczekiwań. Poziom tego ryzyka oznacza jego wielkość lub kombinację kilku ryzyk, która wyrażona jest w postaci kombinacji następstw oraz ich prawdopodobieństwa. Aby poznać charakter tego ryzyka i określenie jego poziomu, należy wykonać analizę ryzyka [7].

Przeprowadzenie oceny ryzyka pełni istotną rolę w dobrowolnych systemach regulujących wymagania zrównoważonego rozwoju dotyczące wykorzystania biomasy do celów energetycznych. Podejmowanie działań promujących takie zastosowanie biomasy wydatnie przyczynia się do ochrony klimatu i redukcji emisji ditlenku węgla do atmosfery. Podstawowym aktem prawnym uwzględniającym powyższe wymagania jest dyrektywa Parlamentu Europejskiego i Rady 2009/28/WE z dnia 23 kwietnia 2009 r. w sprawie promowania stosowania energii ze źródet odnawialnych zmieniajaca $i$ w nastepstwie uchylajaca dyrektywy 2001/77/WE oraz 2003/30/WE (zwana dyrektywą RED) [3]. Kraje członkowskie, na mocy krajowych rozporządzeń w sprawie zrównoważonego rozwoju, dokonały transpozycji europejskich regulacji prawnych w odniesieniu do wykorzystania odnawialnych źródeł energii w zakresie kryteriów zrównoważonego rozwoju biopaliw i biopłynów. Wytyczne zawarte w rozporządzeniach dotyczących zrównoważonego rozwoju obejmują cały cykl życia biopaliw, biopłynów, biokomponentów, począwszy od etapu uprawy surowca do ostatecznego zużycia biopaliw i biopłynów, z uwzględnieniem etapów pośrednich (skupu, pośrednictwa, przetwarzania biomasy).

Każdy system certyfikacji, którego celem jest wykazanie zgodności z kryteriami zrównoważonego rozwoju zawartymi w dyrektywach Parlamentu Europejskiego, musi zostać uznany i zatwierdzony przez Unię Europejską. Obecnie (stan na dzień 20.09.2015 r.) na liście zatwierdzonych systemów znajduje się 19 dobrowolnych standardów [1], w tym KZR INiG, REDcert i ISCC.

\section{Cel i zakres stosowania oceny ryzyka wobec podmiotu przystępującego do certyfikacji}

Każdy podmiot zgłaszający do jednostki certyfikującej chęć uzyskania certyfikatu na zgodność z wymogami dyrektywy RED zostaje poddany ocenie wysokości ryzyka. Jest to proces zmierzający do poznania charakteru ryzyka i określenia jego poziomu, którego wielkość jest wyrażona w postaci kombinacji następstw i ich możliwości rzutujących na prawidłowe funkcjonowanie organizacji w obszarze wymogów wybranego systemu certyfikacyjnego. W zależności od przyjętej metody może być ona wyrażona ilościowo, w po- staci konkretnej wartości liczbowej, lub opisowo, np.: małe, średnie, wysokie ryzyko. Jednostka certyfikująca, uzyskując wiedzę o ryzyku oszacowanym dla danego podmiotu, ma możliwość wybrania właściwego wariantu postępowania, w którego efekcie podejmowana jest decyzja o przyznaniu lub nieprzyznaniu certyfikatu zgodności.

$\mathrm{Z}$ uwagi na fakt, że systemy certyfikacji obejmują swoim zakresem cały cykl życia biopaliw - od siewów do produkcji paliwa finalnego - w ocenie ryzyka podmiotu muszą być 
wzięte pod uwagę te obszary, które mają bezpośredni wpływ na realizację zadeklarowanego zakresu. Przykładem może być producent rolny, wobec którego podczas oceny ryzyka bierze się pod uwagę m.in. wielkość areału i powierzchnię upraw, po- łożenie geograficzne i lokalizację w odniesieniu do obszarów właściwych, takich jak np. Natura 2000. Częstym rozwiązaniem stosowanym przez jednostki certyfikujące są odrębne analizy ryzyka przygotowane z myślą o konkretnych zakresach.

\section{Ocena ryzyka w systemie KZR INiG}

Każda jednostka certyfikująca jest zobowiązana do przeprowadzenia oceny ryzyka przed wykonaniem audytu, zgodnie z wymaganiami systemu KZR INiG. Sposób, w jaki ma być przeprowadzona, nie jest określony, stąd też występuje tu pełna dowolność. Jednostka certyfikująca SGS Polska w swojej procedurze dotyczącej certyfikacji zrównoważonego rozwoju w produkcji biopaliw i biopłynów opisała dwa sposoby szacowania ryzyka, które przedstawiono poniżej.

Dla producentów rolnych przeprowadza się analizę ryzyka przed audytem, z uwzględnieniem współczynników ryzyka określonych w systemie KZR INiG, których sposób wykorzystania określa właściciel standardu - Instytut Nafty i Gazu - PIB. Punktem wyjściowym w szacowaniu ryzyka są adresy producentów, których lokalizacje weryfikuje się w bazach danych: World Database on Protected Areas (WDPA), Natura 2000, Centralnym Rejestrze Form Ochrony Przyrody (CRFOP), bazie Generalnej Dyrekcji Ochrony Środowiska oraz w Geoserwisie. W zależności od położenia gospodarstwa szacuje się:

- ryzyko wysokie - w przypadku obszarów chronionych położonych w promieniu do $2 \mathrm{~km}$ od gospodarstwa rolnego,

- ryzyko średnie - w przypadku obszarów chronionych znajdujących się w promieniu od $2 \mathrm{~km}$ do $5 \mathrm{~km}$ od gospodarstwa rolnego,
- ryzyko niskie - w przypadku obszarów znajdujących się co najmniej $5 \mathrm{~km}$ od gospodarstwa rolnego.

W szacowaniu poziomu ryzyka dla grupy producentów rolnych klasyfikacja tego wskaźnika jest średnią ważoną poziomów ryzyka reprezentowanych przez wszystkich producentów stanowiących badaną grupę. Poziom ryzyka dla pojedynczego członka grupy ma przyporządkowaną jedną z wartości:

- ryzyko niskie - 1 punkt,

- ryzyko średnie - 2 punkty,

- ryzyko wysokie -3 punkty.

Po przyporządkowaniu kolejnych wartości punktowych poszczególnym producentom następuje zsumowanie punktów, a w dalszej kolejności otrzymana wartość dzielona jest przez liczbę podmiotów w grupie, co w efekcie daje poziom ryzyka dla danej grupy producentów. W zależności od otrzymanego wyniku definiuje się ryzyko niskie, średnie lub wysokie [11]. Stwierdzenie średniego lub wysokiego ryzyka skutkuje pomnożeniem danej próbki reprezentacyjnej przez współczynnik podany w tablicy 1 [10].

W sytuacjach, gdy większość producentów rolnych kwalifikuje się do grupy o niskim ryzyku, dodatkowymi czynnikami decydującymi o doborze próby są m.in.: wielkość gospodarstwa i/lub ilość dostarczanej zrównoważonej biomasy,

Tablica 1. Współczynniki ryzyka wykorzystywane w systemie KZR INiG dla producentów rolnych [10]

\begin{tabular}{|c|c|c|}
\hline Rodzaj ryzyka & Opis & Mnożnik \\
\hline Niskie & $\begin{array}{l}\text { - Gospodarstwo rolne znajduje się na terenie Unii Europejskiej, brak znanych informacji o konfliktach } \\
\text { związanych ze sposobem wykorzystania gruntów } \\
\text { - Brak ekspansji powierzchni pod uprawę surowców } \\
\text { - Kompletność i aktualność dokumentów } \\
\text { - Dostępne są deklaracje własne producentów rolnych }\end{array}$ & 1 \\
\hline Średnie & $\begin{array}{l}\text { - Gospodarstwa rolne nie znajdują się w pobliżu obszarów ryzyka (obszary leśne, torfowiska, tereny } \\
\text { podmokłe, tereny zielone o wysokiej wartości biologicznej) } \\
\text { - Nieznaczne zwiększenie powierzchni pod uprawę biomasy } \\
\text { - Istnieją nieznaczne braki w dokumentacji administracyjnej u pierwszego podmiotu skupującego } \\
\text { - Deklaracje własne producentów rolnych w zakresie zrównoważonej produkcji biomasy są niepełne } \\
\text { lub nieaktualne } \\
\text { - Stwierdzono niewielkie niezgodności podczas ostatniego audytu }\end{array}$ & 1,5 \\
\hline Wysokie & $\begin{array}{l}\text { - Gospodarstwa rolne znajdują się blisko obszarów ryzyka (obszary leśne, torfowiska, tereny } \\
\text { podmokłe, tereny zielone o wysokiej wartości biologicznej) } \\
\text { - Znane są informacje o istniejących konfliktach związanych ze sposobem użytkowania gruntów } \\
\text { - Zamierzona ekspansja powierzchni pod uprawę } \\
\text { - Brak wymaganej dokumentacji systemowej (np. brak deklaracji własnej producenta rolnego } \\
\text { w zakresie zrównoważonej produkcji biomasy może powodować problemy z zagwarantowaniem } \\
\text { spełnienia kryteriów zrównoważonego rozwoju (głównie art. } 17 \text { ust. 2-5)) } \\
\text { - Brak działań korygujących po stwierdzeniu niezgodności podczas ostatniego audytu }\end{array}$ & 2 \\
\hline
\end{tabular}


kompletność i aktualność dokumentów czy ekspansja powierzchni pod uprawę surowców.

W przypadku podmiotów niebędących producentami rolnymi, a zgłaszających potrzebę uzyskania certyfikatu w ramach systemu KZR INiG przeprowadza się analizę ryzyka na specjalnym formularzu, opracowanym przez SGS Polska. Informacje, które są potrzebne do oszacowania ryzyka dla tych podmiotów, zawarte są m.in. we wniosku o certyfikację, w raporcie z poprzedniej kontroli (jeśli miała miejsce), jak również w źródłach ogólnodostępnych. Formularz ma formę haseł $\mathrm{z}$ co najmniej trzema wariantami odpowiedzi. Każda odpowiedź ma przypisaną określoną wartość liczbową, uzależnioną od istotności i wpływu danego czynnika na zakres poddany certyfikacji. Otrzymana suma punktów pozwala określić stopień ryzyka, a w konsekwencji sposób nadzoru jednostki certyfikującej nad danym podmiotem [9].
Do czynników mających wpływ na stopień ryzyka należą m.in.: okres działalności i doświadczenie podmiotu w obszarze certyfikowanego zakresu, liczba zakresów, lokalizacji, producentów rolnych (jeśli dotyczy) zgłoszonych do certyfikacji. W przypadku gdy dany podmiot uczestniczył w poprzednim roku w systemie certyfikacji wybranego etapu w całym łańcuchu życia biopaliw, uwzględnia się także niezgodności, jeśli zostały stwierdzone, oraz czas wdrożenia działań naprawczych. Pod uwagę bierze się również wszelkie informacje dotyczące danego podmiotu pochodzące od innych jednostek certyfikujących i/lub właścicieli tożsamych standardów.

Obie analizy ryzyka opracowane i wykorzystywane w procesie certyfikacji przez SGS Polska wykazały dużą skuteczność. Właściwe oszacowanie poziomu ryzyka w przypadku producentów rolnych potwierdzone było podczas audytów, a audytorzy nie zgłaszali zastrzeżeń w zakresie typowanych gospodarstw.

\section{Ocena ryzyka w systemie REDcert}

Zgodnie z wymaganiami właściciela standardu REDcert jednostka certyfikująca jest zobowiązana prowadzić stosowną analizę ryzyka, mającą na celu oszacowanie poziomu ryzyka w zakresie funkcjonowania podmiotów certyfikowanych/ ubiegających się o certyfikację w ramach łańcuchów dostaw surowca dla branży paliwowej. Proces oceny podmiotu obejmuje co najmniej dwa etapy, a w przypadku grup producentów płodów rolnych lub podmiotów skupujących biomasę bezpośrednio od producentów pierwotnych - nawet trzy.

Podstawową analizą ryzyka przeprowadzaną przez jednostkę certyfikującą jest ocena zakresu działalności podmiotu ubiegającego się o certyfikację i określenie wymagań, względem których oceniana będzie dana firma. Wiąże się to z pozyskaniem od tego podmiotu stosownych informacji na temat obowiązujących $\mathrm{w}$ nim procedur, charakteru prowadzonej działalności, skomplikowania struktury organizacyjnej, wreszcie stopnia złożoności procesów toczących się w organizacji przystępującej do certyfikacji. Zgromadzone informacje stanowią podstawę do dobrania audytora - kompetentnego i z doświadczeniem zawodowym - który będzie w stanie przeprowadzić kolejny etap analizy ryzyka, czyli proces audytu, na podstawie list kontrolnych opracowanych przez operatora standardu REDcert. Jest to podyktowane wymogiem zarządzania ryzykiem przez jednostki certyfikujące w odniesieniu do ich klientów ([12], punkt 3.3.1 Zarzadzanie ryzykiem).

Ocena poddającego się certyfikacji podmiotu odbywa się na podstawie kryteriów zawartych w listach kontrolnych systemu REDcert. Standard już sam w sobie wskazuje krytyczne obszary, których wymogi muszą być obligatoryjnie spełnione przez wszystkie ogniwa łańcucha dostaw - kryteria takie oznaczone są jako KO (ang. knock out - nokaut). Niespełnienie któregokolwiek z tak oznaczonych kryteriów dyskwalifikuje podmiot ubiegający się o certyfikację i uniemożliwia wydanie certyfikatu ([12], punkt 1.4 Ocena wyników kontroli). Pozostałe kryteria oceny muszą być spełnione na łącznym poziomie co najmniej $75 \%$ i rolą audytora jest dokonanie stosownej analizy ryzyka dla źródeł danych oraz informacji prezentowanych przez audytowanego, tak by móc ocenić, w skali punktowej, każde kryterium kontroli (tablica 2), a ostatecznie z całą pewnością stwierdzić, czy dana firma spełnia kryteria krytyczne (KO) oraz odpowiednią liczbę pozostałych wymogów.

Ostatni typ analizy ryzyka dotyczy grup producenckich oraz firm zajmujących się handlem z producentami pierwotnymi płodów rolnych $\mathrm{i}$ wiąże się $\mathrm{z}$ doborem reprezentatywnej próbki dostawców uczestniczących w obrocie biomasą. Wyjściowym założeniem jest zweryfikowanie jej minimalnej liczności jako pierwiastka kwadratowego całkowitej liczby zaopatrujących podmiot producentów rolnych. Metodologia wyboru dostawców z badanej grupy pozostawiona jest audytorowi, jako że to jego rolą jest analiza danych dostępnych w przedsiębiorstwie i tym samym trafny wybór producentów rolnych, którzy powinni zostać zwizytowani. Najpowszechniejsze są dwa kryteria doboru, tj. kryterium geograficzne, czyli położenie względem obszarów wrażliwych - parków narodowych, rezerwatów biosfery, rzek itd., oraz kryterium ilościowe, polegające na wyborze gospodarstw o dużej powierzchni i/lub dostarczających duże ilości biomasy do certyfikowanej firmy, stanowiące jednocześnie istotny procent 
Tablica 2. Możliwości oceny wymagań w systemie REDcert [12]

\begin{tabular}{|c|l|c|}
\hline Ocena & \multicolumn{1}{|c|}{ Oświadczenie } & Liczba punktów \\
\hline A & Całkowita zgodność & 20 \\
\hline B & Prawie całkowita zgodność & 15 \\
\hline C & Jedynie częściowe wypełnienie wymagań systemowych & 5 \\
\hline D & Brak wypełnienia wymagań systemowych & 0 \\
\hline Nie dotyczy & $\begin{array}{l}\text { Wymagania systemowe nie mają zastosowania. (Wymagania ocenione symbolem nie dotyczy } \\
\text { wymagają uzasadnienia w raporcie kontrolnym). Nie wszystkie kryteria można oceniać terminem } \\
\text { nie dotyczy }\end{array}$ & 0 \\
\hline
\end{tabular}

całkowitego obrotu. W sytuacji, gdy aż $1 / 3$ wytypowanych producentów nie spełnia wymagań systemowych, pierwotnie określona próba ulega podwojeniu w celu dokładniejszej weryfikacji. Gdy i w kolejnej partii ponad 1/3 dostawców nie spełnia wymogów kontroli, następuje kolejne po- dwojenie próby. System REDcert zakłada, że hipotetycznie może dojść do weryfikacji 100\% dostawców w czasie jednego audytu. Długoterminowo taki jest też cel systemu - aby w okresie kolejnych sezonów dążyć do potwierdzenia zgodności z wymaganiami standardu u $100 \%$ jego uczestników.

\section{Ocena ryzyka w systemie ISCC}

System ISCC zakłada dwa typy analizy ryzyka wykonywanej w ramach certyfikacji podmiotów chcących uzyskać potwierdzenie zgodności z zasadami programu.

Pierwszy typ szacowania ryzyka jest obligatoryjny dla każdego podmiotu przystępującego do systemu i dotyczy oceny przedsiębiorstwa pod kątem transparentności i poprawności jego funkcjonowania. Rolą audytora w pierwszej fazie audytu jest dokonanie przeglądu działalności podmiotu i określenie, czy w prawidłowy sposób prowadzone są procesy wymagane przez wdrożony system jakości, jak też zasady systemu ISCC. Do ocenianej dokumentacji należą np.: umowy z dostawcami i odbiorcami biomasy, stosowne pozwolenia czy licencje, potwierdzenie należytej dbałości o stan infrastruktury pomiarowej, dokumentacja związana ze stanami magazynowymi (dokumenty WZ i PZ), dokumenty potwierdzające kompetencje personelu, opis procesów i ich odzwierciedlenie w rzeczywistości, wewnętrzny system jakości, zapisy z audytów wewnętrznych [4]. W zależności od stopnia kompletności i dostępności dokumentacji audytor poprzez jej ocenę szacuje poziom ryzyka wystąpienia niezgodności mogących w audytowanej firmie doprowadzić do niewłaściwego obrotu zrównoważoną biomasą. Poziomy, do których audytujący może zaliczyć dowody przedstawione przez podmiot, są trzy: normalny (ang. regular risk), średni (ang. medium risk) i wysoki (ang. high risk) i w zależności od poziomu ryzyka audyt będzie miał inną intensywność, a tym samym nieco inny przebieg. W przypadku poziomu normalnego audytor poddaje ocenie losowo wybraną dokumentację z okresu trzech miesięcy poprzedzających audyt. Dla poziomu średniego są to losowo wybrane dokumenty oraz pełna analiza dokumentacji z wybranego jednego miesiąca, natomiast poziom wysoki wymaga kompletnej weryfikacji okresu, na który składają się trzy następujące po sobie miesiące.

Drugi typ analizy ryzyka dotyczy wyboru reprezentatywnej próbki dostawców biomasy do zwizytowania w ramach procesu audytowego grup producenckich oraz tzw. punktów pierwszego zbioru. Podobnie jak w większości systemów certyfikacji biomasy na cele paliwowe punktem wyjścia jest oszacowanie liczebności próbki i za podstawę oceny uznaje się pierwiastek kwadratowy całkowitej puli producentów pierwotnych. Następnie, zgodnie w wytycznymi systemu ISCC, wyboru producentów rolnych dokonuje się na podstawie dwóch kluczowych czynników wskazanych przez system, tj. lokalizacji produkcji (odległość od miejsc, w których nie powinna być prowadzona produkcja rolna, np. parków narodowych, rezerwatów biosfery itp. - tzw. no-go areas) oraz statusu gruntów ornych w użytkowaniu (tj. czy grunty miały status gruntu rolnego przed 1 stycznia 2008 r., czy też wystapiły zmiany statusu wiążące się z kalkulacją GHG) [5]. Najczęściej weryfikowanym kryterium jest odległość gospodarstw od obszarów chronionych i na tej właśnie podstawie dokonuje się oceny wszystkich producentów pierwotnych - gdy gospodarstwo znajduje się powyżej $10 \mathrm{~km}$ od najbliższego obszaru chronionego, poziom ryzyka określa się jako normalny; dla producentów położonych w odległości od $5 \mathrm{~km}$ do $10 \mathrm{~km}$ ryzyko szacowane jest na poziomie średnim; dla producentów znajdujących się mniej niż $5 \mathrm{~km}$ od obszarów chronionych zakłada się wysoki poziom ryzyka. Po wyznaczeniu poziomu ryzyka dla każdego podmiotu poprzez ustalenie procentowego udziału poszczególnych poziomów wskazuje się dla całego ocenianego zbioru tzw. współczynnik ryzyka, który jest mnożnikiem dla 
podstawowej liczby, czyli pierwiastka kwadratowego wejściowej zbiorowości podlegającej selekcji. Współczynnik ten przyjmuje wartość [6]:

- 1 - gdy nie ma wielu gospodarstw leżących w pobliżu obszarów wrażliwych,

- 1,5 - gdy znacząca liczba gospodarstw znajduje się w pobliżu obszarów chronionych,

- 2 - gdy ponad połowa gospodarstw leży mniej niż $10 \mathrm{~km}$ od obszarów chronionych.

Tak wyselekcjonowana próbka podlega wizytacjom w celu oceny kryteriów założonych przez system ISCC. W przypadku gdy przynajmniej jedno gospodarstwo nie spełnia kryteriów, wybrana próba podlega podwojeniu, aż do uzyskania spełnienia wymogów przez wszystkie wizytowane podmioty. Właściciel systemu ISCC dopuszcza powiększanie próbki do uzyskania 100\% jej liczebności, jako że jednym z założeń systemu jest dążenie w czasie wieloletniej certyfikacji do zweryfikowania możliwie wielu podmiotów (w tym także producentów pierwotnych) składających się na łańcuch dostaw biomasy na cele biopaliwowe.

\section{Podsumowanie}

Oszacowanie ryzyka dla danego podmiotu podlegającego audytowi certyfikującemu ma istotne znaczenie w dalszym procesie. Przypisany poziom ryzyka przed przystąpieniem do oceny podmiotu daje możliwość określenia wielkości próbki badanej podczas audytu, celem dokładnego przeanalizowania procesu realizowanego $\mathrm{w}$ przedsiębiorstwie zgodnie z wymogami realizowanego standardu.

Jak opisano powyżej, każdy system certyfikacji biomasy na cele biopaliwowe wymaga oceny ryzyka w certyfikowanym zakresie, co ma kluczowe znaczenie w całym procesie. $\mathrm{Z}$ uwagi na fakt, że systemy ISCC i REDcert funkcjonują na rynku już kilka lat, zdobyte doświadczenie w sposobie ich funkcjonowania przyczyniło się do opracowania przez operatorów tych systemów szczegółowych wytycznych w zakresie przeprowadzania analizy ryzyka danego podmiotu. Polski system KZR INiG, ze względu na swoją niedługą obecność na liście zatwierdzonych przez Komisję Europejską standardów certyfikacji biomasy, nie określa jednoznacznie, w jaki sposób jednostki certyfikujące powinny przeprowadzać analizę ryzyka w stosunku do certyfikowanych przedsiębiorstw. Efektem takiego podejścia są różne rozwiązania przyjmowane przez jednostki certyfikujące, co niejednokrotnie może nieść ze sobą ryzyko nieprawidłowej oceny podmiotu.

Doświadczenie pokazuje, że pozytywny wynik audytu we wcześniejszych latach nie jest gwarantem niskiego ryzyka w kolejnych cyklach certyfikacyjnych. Realizacja procesu $\mathrm{w}$ danej jednostce podlegającej ocenie nie ma jednoznacznego wpływu na poziom ryzyka, dlatego tak istotne jest, by analizę ryzyka przeprowadzać regularnie na podstawie zgromadzonych informacji.

Prosimy cytować jako: Nafta-Gaz 2016, nr 5, s. 364-369, DOI: 10.18668/NG.2016.05.08

Artykuł nadesłano do Redakcji 9.11.2015 r. Zatwierdzono do druku 3.02.2016 r.

\section{Literatura}

[1] Directorate-General for Energy, European Commission: Voluntary schemes, http://ec.europa.eu/energy/en/topics/ renewable-energy/biofuels/voluntary-schemes (dostęp: 20.09.2015)

[2] Tarczyński W., Mojsiewicz M.: Zarzadzanie ryzykiem. Warszawa, PWE, 2001

\section{Akty prawne i normatywne}

[3] Dyrektywa Parlamentu Europejskiego i Rady 2009/28/WE z dnia 23 kwietnia 2009 r. $w$ sprawie promowania stosowania energii ze źródeł odnawialnych zmieniajaca $i$ w następstwie uchylajaca dyrektywy 2001/77/WE oraz 2003/30/WE.

[4] ISCC: 4.3.1 General risk indicators. [W:] ISCC 207 - Risk Management. ISCC 11-03-15 V 2.3-EU.

[5] ISCC: 4.3.2 Supplementary risk indicators for farms. [W:] ISCC 207 - Risk Management. ISCC 11-03-15 V 2.3-EU.

[6] ISCC: 4.4.3 Evaluation. [W:] ISCC 207 - Risk Management. ISCC 11-03-15 V 2.3-EU.

[7] ISO 31000 Risk management - Principles and guidelines (PN-ISO 31000:2012 Zarzadzanie ryzykiem - Zasady $i$ wytyczne).
[8] ISO Guide 73:2009 Risk management - Vocabulary (Przewodnik PKN-ISO Guide 73:2012, Zarzadzanie ryzykiem - Terminologia).

[9] LPPL 22 Certyfikacja zrównoważonego rozwoju w produkcji biopaliw i biopłynów KZR INiG. Wyd. 3, SGS Polska, 11.08.2015.

[10] Wytyczne dla audytora i prowadzenia audytu. System KZR INiG-PIB/10. Wyd. 1, Kraków, 5.06.2014.

[11] Załącznik nr 6 do procedury LPPL 22 - Analiza ryzyka dla gospodarstw rolnych. Wyd. 2, SGS Polska, 11.08.2015.

[12] Zasady systemowe dotyczace kontroli neutralnej. REDcert, wersja EU 04 z dnia 18.06.2014.

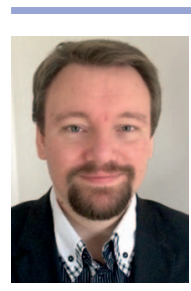

Mgr inż. Piotr NOWACKI

Kierownik Usług Żywnościowych w Branży Agriculture, Food and Life SGS Polska Sp. z o.o.

ul. Bema 8

01-233 Warszawa

E-mail: piotr.nowacki@sgs.com 